Selcuk Journal of Agriculture and Food Sciences

http://sjafs.selcuk.edu.tr/sjafs/index

Research Article
SJAFS

(2019) 33 (2), 148-153

e-ISSN: 2458-8377

DOI:10.15316/SJAFS.2019.168

\title{
Agronomic Characteristics of Domestic and Abroad Originated Bean (Phaseolus vulgaris $\mathbf{L}$.) Genotypes
}

\author{
Mehmet GÜÇLÜ ${ }^{1, *}$, Mustafa ÖNDER ${ }^{2}$ \\ ${ }^{1}$ Selçuk University, Graduate School of Natural Sciences, Department of Field Crops, Konya, Turkey \\ ${ }^{2}$ Selçuk University, Faculty of Agriculture, Department of Field Crops, Konya, Turkey
}

\begin{tabular}{l}
\hline ARTICLE INFO \\
\hline Article history: \\
Received date: 31.05 .2019 \\
Accepted date: 07.07 .2019 \\
\hline Edited by: \\
Ali KAHRAMAN; Selçuk University, \\
Turkey \\
Reviewed by: \\
Ercan CEYLAN; Selçuk University, \\
Turkey \\
Çetin PALTA; Necmettin Erbakan Uni- \\
versity, Turkey \\
\hline Keywords: \\
Breeding \\
Genetic diversity \\
Gremplasm \\
Introduction \\
Selection \\
Yield
\end{tabular}

\section{Introduction}

Genetic diversity of the plants is quite important for many purposes in agricultural production and achievement of nutritional quality that are serving on genetic studies and biotechnology, quality focused studies etc. agronomical and breeding works (Önder and Kahraman, 2008; Ceyhan and Kahraman, 2013; Joshi, 2015; Kahraman and Onder, 2018). There are many genotypes of the dry beans (Phaseolus vulgaris L.) over the world that is including the local ecotypes as well which are presenting quite different statues by view of shape, morphology, chemical composition, nutritional statues, genetic structure and diversity, adaptation statues especially for sowing time, phonological characteristics, morphological statues, cultivation necessaries (Ceyhan et al, 2012; 2014; Onder et al., 2013; Yadav et al., 2015; Harmankaya et al., 2016; Kahraman, 2017). It is well known that, dry bean - as a legume crop, is essential for human due to be an important protein source, vitamin, fiber, diet food, cheap price, easy cultivation and adaptation besides take a

\footnotetext{
*Corresponding author email: mehmetgucl@gmail.com
}

wide part in the markets over the world in addition to act on sustainability of healthy food production, improvement of soil characteristics and a well alternative for crop rotation programs etc. main concept of sustainable agriculture (Kahraman et al., 2015; Kosev and Naydenova, 2015; Kahraman, 2016; Öktem, 2016).

In Turkey, in the field of cultivation and production, after the chickpea and lentil in the edible legumes, the third place is beans. Dry beans is a legume plant known in our country for many years, cultivated and used in human nutrition, animal nutrition and soil improvement. In our country, dry bean cultivation areas have increased in general until 2002. Bean planting areas, which reached the highest level with 180,000 ha in 2002, have decreased gradually in the following years. The Dry bean production in our country was 84.763 ha area and have an average production capacity of $266 / \mathrm{kg} / \mathrm{da}$ and 239.000 tons in 2017. (Anonymous, 2017). In Konya, where the most dry bean production was made, the cultivation area was 19.143 ha, the production was 70.242 tons and the average yield was $366.91 \mathrm{~kg} / \mathrm{da}$. In our country, until 1987, dry beans were not imported. Although 87.940 tons of dry 
beans were exported in 1997, Turkey has become an importer in recent years (Anonymous, 2012).

Nearly half of the total edible legumes cultivation area in the world belongs to dried beans (Anonymous, 2012). In general, 5 of the 50 Phaseolus species (Phaseolus vulgaris, Phaseolus lunatus, Phaseolus coccineus, Phaseolus acutifolius and Phaseolus poliantus) are cultivated for human consumption. In this species, Phaseolus vulgaris species is reported to cover $75 \%$ of the world's cultivated beans and is the most cultivated species (Singh, 1999; Broughton et al., 2003).

Dry bean cultivation is widespread in the temperate regions of the world and is carried out in Asia and South America continents, mostly in developing countries with a high rate of $94 \%$. In the world in 2012, the total cultivation area of dried beans was 28.780 .376 ha and the total production was 23.140.276 tons and the average yield was $80.40 \mathrm{~kg} / \mathrm{ha}$. Looking at the production of beans by country, Myanmar (5.190.000 tons), India (3.898.000 tons) and Brazil (2.616.000 tons); in terms of cultivation area, India (9.100.000 ha), Myanmar (2.845.662 ha) and Brazil (2.726.932 ha) respectively (Anonymous, 2016). When the data of
FAO until 2012 are examined; in the last 5 years, there has been no significant decrease in dry bean cultivation areas around the world. (Dried bean plantation area in the world in 2011 was 30.411 .203 ha, this value decreased to 28.780 .376 ha in 2012 only) And the world's most cultivated field and production of edible grain legume plant has been again dry beans.

Present research is realized to determine some agronomic characteristics of the dry bean genotypes which are originated from domestic and abroad sources under Konya - Turkey ecology that is an important producer over the country for the aim of scanning the significant characteristics for future breeding programs.

\section{Materials and Methods}

This research was carried out in a farmer field in Konya Province, Çumra District and İçeri Çumra Province in 2017. In the research, 100 bean genotypes (Phaseolus vulgaris L.) and 3 standard varieties (Alberto, Kantar, Elkoca) obtained from Selcuk University Faculty of Agriculture Department of Field Crops were used as materials. (Table 1)

Table 1

Local names and numbers of bean genotypes used in research

\begin{tabular}{|c|c|c|c|c|c|c|c|}
\hline No & Local Name & No & Local Name & No & Local Name & No & Local Name \\
\hline 1 & Bonvert & 26 & O-683 & 51 & Bayo & 76 & Canario \\
\hline 2 & Cuarenteno & 27 & Negro & 52 & Brown & 77 & Pinto Mestizo \\
\hline 3 & $\mathrm{G} 47$ & 28 & Chase & 53 & Coulee & 78 & Ac Argonaut \\
\hline 4 & Rice & 29 & California LRK & 54 & Colorado de Comitan & 79 & Fiero \\
\hline 5 & Idaho Brown & 30 & $\begin{array}{l}\text { White Seeded Tender- } \\
\text { green }\end{array}$ & 55 & Callacatlan Frijol & 80 & Red-white \\
\hline 6 & Ayufracho & 31 & Green Isle & 56 & Burros Argentinos & 81 & Ac Black Diamond \\
\hline 7 & Golden Shower & 32 & Mammoth Stringless & 57 & Early Rose & 82 & G62 \\
\hline 8 & Alubia Cerrillos & 33 & Lapin & 58 & Golden Early & 83 & Bonanza \\
\hline 9 & G18706 & 34 & Great Northern 1140 & 59 & Berrenclo & 84 & Q-719 \\
\hline 10 & $\begin{array}{l}\text { Roger Stringless } \\
\text { green refugee }\end{array}$ & 35 & Jalo EEP558 & 60 & Talete & 85 & Radical San Gil \\
\hline 11 & Norida & 36 & Blue Victor & 61 & Pole bean & 86 & Cameleon \\
\hline 12 & Cuarenteno & 37 & Yamal & 62 & Redswan & 87 & Amadeus 77 \\
\hline 13 & Frijol Tinequito & 38 & Dresden & 63 & Richgreen & 88 & Mecosta \\
\hline 14 & Louisiana & 39 & Montequilla & 64 & Dwarf & 89 & Ac Scarlet \\
\hline 15 & Bayo & 40 & G1924 & 65 & Hungarian & 90 & Salem \\
\hline 16 & Pinto Bayacora & 41 & $\begin{array}{c}\text { Dwarf Green Round } \\
\text { Pod }\end{array}$ & 66 & Swedish Brown & 91 & $\begin{array}{l}\text { Round Pod Kidney } \\
\text { Wax }\end{array}$ \\
\hline 17 & Montequilla & 42 & San Juan & 67 & Drought Resistant & 92 & Arikara Yellow \\
\hline 18 & Toramane & 43 & G31 & 68 & Mortino & 93 & Black Turtle Soup \\
\hline 19 & Blue Danube & 44 & Bush Bean & 69 & Acotlanero Negro & 94 & G V 50 \\
\hline 20 & Chile & 45 & Polaris & 70 & $\mathrm{G} 2453$ & 95 & Lakette \\
\hline 21 & Holberg & 46 & Monument & 71 & Blush & 96 & Brown Dwarf \\
\hline 22 & Emerson & 47 & İmperial Pea Bean & 72 & Golden & 97 & Frijol Aluvia \\
\hline 23 & $\begin{array}{c}\text { Genetic Marker } \\
17\end{array}$ & 48 & Frijol Tinequito & 73 & $\begin{array}{l}\text { Oregon Brown } \\
\text { Greasy }\end{array}$ & 98 & No.1072 \\
\hline 24 & $\begin{array}{c}\text { Norwegian } \\
\text { Brown }\end{array}$ & 49 & Colombia & 74 & Claret & 99 & Delgado \\
\hline 25 & Horticultural & 50 & Talete & 75 & Bigbend & 100 & Niagara 773 \\
\hline
\end{tabular}

Some physical and chemical properties were determined as a result of the analysis of the experimental

area soil. The soil of the trial area has a slightly alkaline structure and $\mathrm{pH}$ is 7.86 and the ratio of organic 
matter is $0.91 \%$. Available Phosphorus content is 13.66 $\mathrm{kg} / \mathrm{ha}$, Available Potassium ratio is $190.55 \mathrm{~kg} / \mathrm{da}$ and the micro element ratios are sufficient (Table 2).

Table 2

Important Soil Properties of the Trial Field

\begin{tabular}{lcc}
\hline Analysis Name & Unit & Results \\
\hline Structure & $\%$ & 55 \\
Salinty & $\%$ & 0,02 \\
$\mathrm{pH}$ & & 7.86 \\
E.C. & $\%$ & 489 \\
Organic Matter & $\%$ & 0.91 \\
Lime & $\mathrm{Kg} / \mathrm{da}$ & 13.66 \\
Availabe Phosphorus $\left(\mathrm{P}_{2} \mathrm{O}_{5}\right)$ & $\mathrm{Kg} / \mathrm{da}$ & 190.55 \\
Availabe Potassium $\left(\mathrm{K}_{2} \mathrm{O}\right)$ & $\mathrm{Ppm}$ & 5629 \\
Calcium & $\mathrm{Ppm}$ & 741 \\
Magnesium & $\mathrm{Ppm}$ & 2.55 \\
Iron & $\mathrm{ppm}$ & 0.60 \\
Copper &
\end{tabular}

The average temperature demand of beans during the developments and flovering period is $20-25{ }^{\circ} \mathrm{C}$ (Şehirali 1979). In 2017, the average temperature was suitable for bean cultivation.(Table 3).

Table 3

Climate Data In Çumra District Of Konya Province Of Vegetation Period

\begin{tabular}{|c|c|c|c|c|}
\hline \multirow[t]{2}{*}{ Montths } & \multicolumn{2}{|c|}{$\begin{array}{l}\text { Monthly Average } \\
\text { Temperature }\left({ }^{0} \mathrm{C}\right)\end{array}$} & \multicolumn{2}{|c|}{$\begin{array}{l}\text { Monthly Total Rainfall } \\
\text { (mm) }\end{array}$} \\
\hline & $\begin{array}{c}\text { Long Term } \\
\text { (30 Years) }\end{array}$ & 2017 & $\begin{array}{c}\text { Long Term } \\
(30 \text { Years) }\end{array}$ & 2017 \\
\hline April & 11,3 & 11,4 & 36,6 & 60,4 \\
\hline May & 15,7 & 15,8 & 35,5 & 58,6 \\
\hline June & 19,8 & 20,3 & 19,8 & 14,0 \\
\hline July & 22,9 & 24,5 & 6,9 & 0,0 \\
\hline August & 22,6 & 23,4 & 4,5 & 2,2 \\
\hline September & 18,4 & 21,2 & 11,2 & 0,0 \\
\hline Total & & & 110,4 & 135,2 \\
\hline Average & 16,11 & 19,43 & & \\
\hline
\end{tabular}

Due to the fact that all of the bean genotypes used as materials in the research were obtained from the gene banks and the amount of seed was low and a large number of genotypes were used in the experiment. This research was established according to the Augmented Trial Pattern. In accordance with the characteristics of the Augmented Trial Pattern, in this experiment, which was planned as 6 replicates, the standard varieties were repeated in each block while the genotypes were randomly distributed to the blocks. Each of the genotypes was planted in 1 row of $1 \mathrm{~m}$. Standard varieties were planted in 4 rows of $1 \mathrm{~m}$. Hand plantings were made between $45 \mathrm{~cm}$ in row, $10 \mathrm{~cm}$ over row and $60 \mathrm{~cm}$ between the blocks On the 1st of May 2017. In the 30 $\mathrm{kg}$ DAP formulation (18.46.0), the base fertilizer was applied before the planting. In the trial, totally 6 sprinkler irrigation were applied in the season. In the trial weed control was carried out twice by grubbing.

Hand harvesting and blending were performed on different days in the period when the beans of a large part of each genotype and standard type were yellowed and grains were matured. All the observations were realized according to the UPOV statues. These cultivars and varieties cultivated in the Central Anatolia climate yield, 100 grain weight, plant height, number of branches, number of vetches, number of vetches per plant, vegetation time, such as observations and measurements were made. The statistical analyzes were performed according to "Augmented Design" on these results to determine the performance of some genotypes and some agricultural properties by "JUMP" computer based statistical analysis program.

\section{Results and Discussion}

When the genotypes were evaluated for grain yield, the highest grain yield was obtained from the genotype 2 with $57.28 \mathrm{~g} /$ plant. This was followed by the genotypes 56 (51.9 g / plant) and 75 (50.34 g / plant) in descending order. According to the adaptation to the ecological conditions of Konya, there were genotypes that did not yield, and there were also genotypes giving about $60 \mathrm{~g} /$ plant yield. As a matter of fact, Önder et al. (2013) stated that 41 bean genotype yields varied between 114 and $355 \mathrm{~kg}$ / da. Ülker and Ceyhan (2008) stated that 19 bean genotype yields varied between 162.92-476.85 kg/da. Önder and Özkaynak (1994) stated that 10 bean genotype yields varied between 264.23-358.47 kg/da. When these results are considered, lines 2, 56 and 75 can be used as genetic source in studies to be made for bean improvement. Variance analysis results of the standard varieties used were given (Table 4).

It was determined that there were positivesignificant relationships between seed yield and seed weight in shortie beans. It was determined that the facial weight values showed a wide variation. And this value has ranged from 13.42 to $80.6 \mathrm{~g}$ in various studies. (Çiftçi and Şehirali, 1984; Bozoglu and Sozen, 2007; Kahraman \& Önder, 2009; Gunes, 2011; Basciftci, 2012; Isik, 2012). Amont the Genotypes number18 genotype (61.94 g / plant), genotype 8 (47.94 g / plant) and number 72 genotype (72.61 g / plant) are the most prominent genotypes. 
Table 4

Analysis of variance of the properties examined in the research

\begin{tabular}{lcccccc}
\hline Source of variation & DF & Seed yield & $\begin{array}{c}\text { One hundred seed } \\
\text { weight }\end{array}$ & Plant height & First pod height & Vegetation length \\
\hline Standard & 3 & $* *$ & $* *$ & $* *$ & $*$ & $*$ \\
\hline & $*: \mathrm{p}<0.05 ; * * \mathrm{p}<0.01$ & & & &
\end{tabular}

Among the genotypes used in the study, the plant height was found between 5.28 and $218.61 \mathrm{~cm}$. Similarly to our study results, it has been found that this value changes in a wide range of $1770-310 \mathrm{~cm}$ in various studies in which the plant height is determined in beans. (Şehirali, 1965; Akçin, 1971; Çiftçi and Şehirali, Table 5

Standard types and genotypes according to the characteristics discussed in the minimum-highest values and lsd values.

\begin{tabular}{lccccc}
\hline Characteristics & $\begin{array}{c}\text { Seed Yield }(\mathrm{g} \\
\left.\text { plant }^{-1}\right)\end{array}$ & $\begin{array}{c}\text { One Hundred Seed } \\
\text { Weight }(\mathrm{g})\end{array}$ & Plant Height $(\mathrm{cm})$ & $\begin{array}{c}\text { Vegetation of } \\
\text { Length (days) }\end{array}$ & First Pod Height \\
\hline Min. & 1.9 & 8.28 & 5.28 & 95.94 & 6.78 \\
Max. & 57.28 & 61.94 & 218.61 & 138.27 & 24.45 \\
Alberto & $45.02 \mathrm{a}$ & $33.83 \mathrm{~b}$ & $101.66 \mathrm{a}$ & $109.66 \mathrm{~b}$ & $16.17 \mathrm{a}$ \\
Elkoca & $23.665 \mathrm{~b}$ & $39.83 \mathrm{a}$ & $69.16 \mathrm{~b}$ & $115.66 \mathrm{a}$ & $12.34 \mathrm{~b}$ \\
Kantar & $49.83 \mathrm{a}$ & $40.16 \mathrm{a}$ & $75 \mathrm{~b}$ & $109.5 \mathrm{~b}$ & $12.83 \mathrm{~b}$ \\
\hline LSD $(0.05)$ & 9.043 & 1.887 & 18.247 & 4.527 & 2.985 \\
\hline
\end{tabular}

The number of branches in the plants used in the study was found to be 1.16-4.16 / plant range. Singh et al. (1976) stated that the number of major branch in the plant was an important factor affecting grain yield in dry beans.

The number of vetch in the plant has a significant effect on yield. In genotype analysis, genotype 97 was the genotype with the highest vetch number with 60.94 units / plant. In descending order, genotype 21 followed 53.94 pieces / plant and 80 genotypes with 43.28 pieces / plant. In previous studies, it was determined that beans had a wide variation in terms of vetch number and this value could be in the range of 1-163 pieces / plant. (Önder and Sade, 1996, Düzdemir, 1998; Bozoğlu and Gülümser, 2000; Kaçar et al. 2004; Bozoğlu and Sözen, 2007; Kahraman \& Önder, 2009; Önder et al., 2013)

In the study, the number of grain in the bean was determined as 0.82-6.16 pieces/vetch. The number of vetch grains in the dry bean plant is an important yield component (Adams, 1967). In the studies on the subject, the number of vetch beans in beans was found to be 1.6-6.3. (Çiftçi \& Şehirali, 1984), 1-9 (Anlarsal et al., 2000), 3-7 (Kahraman \& Önder, 2009) and 3.0-5.8 pieces /vetch (Önder et al., 2013). The results of our thesis are similar with previous studies.

The highest initial vetch height was obtained from Alberto variety with $16.17 \mathrm{~cm}$ height as the average of blocks. This was followed by Elkoca and $12.34 \mathrm{~cm}$ Kantar with $12.83 \mathrm{~cm}$ in descending order. Of the genotypes used in the trial, the lowest genotype was number $58(6.78 \mathrm{~cm})$ measured and the highest genotype was number $97(25.45 \mathrm{~cm})$.

There was no significant difference in flowering time between genotypes used in the study. The number
1984; Önder and Özkaynak, 1994; Anlarsal et al., 2000; Kaçar et al., 2004; Karadavut et al., 2005; Pekşen, 2005; Bozoğlu and Sözen, 2007; Ülker and Ceyhan, 2008; Kahraman \& Önder, 2009; Güneş, 2011).
89 genotype (37.94 days), the shortest flowering period of genotypes, and the longest flowering time number 26 genotype (60.94 days) were measured.

The time to flowering in dry beans has been found to have a significant effect on yield (Singh and Malhotra, 1970). And according to the results of the research (Anlarsal et al., 2000; Karadavut et al., 2005; Pekşen, 2005; Ülker and Ceyhan, 2008; Kahraman \& Önder, 2009a; Güneş, 2011), the time to flowering in dry beans varies according to the ecological factors and genotypes and has been found to vary between 36-72 days. Mendes et al. (2008) stated that crossbreeding in dry beans can reduce flowering time from 33.2 to 25.0 days.

The vegetation period was determined as 95.94138.27 days. Gillard et al (2012) in their report on the study of dry beans for 4 years Although the harvest time is commonly referred to as $90 \%$ of the pods in the period of maturation, they stated that this situation is difficult in field conditions, and that if harvest time is not determined correctly, significant decreases in yield and quality may occur.

\section{Conclusion and Suggestions}

This study was carried out in 2017 together with Kantar, Alberto and Elkoca varieties of 100 different dry and fresh bean lines provided by Prof Dr. Mustafa Önder with the introduction method from different countries and regions under the conditions of farmers in the İçeriçumra neighborhood of Çumra district of Konya Province. Results of the study is summarized in the following lines.

Test results showed highest yield in terms of grain yield per plant of $49.83 \mathrm{~g} /$ plant was obtained from the 
Kantar variety. The yields of the genotypes 2, 25, 34, $39,55,56,69,75,89$ and 94 used were close to or high. Similarly, 8 genotypes $(8,18,29,51,71,77,79$, 86) were found in the coarse grains, which weighed $40.16 \mathrm{~g}$ in one hundred grains.

In light of these results genotypes used in this experiment can be used, in the field of cultivation development, which is better in terms of grain yield and important agricultural characteristics used in the experiment.

\section{References}

Adams MW (1967). Basis on yield component compensation in crop plant with special reference to the field beans (Phaseolus vulgaris). Crop Science, (7): 505-510.

Akçin A (1971). Erzurum şartlarında yetiştirilen kuru fasulye çeşitlerinde gübreleme, ekim zamanı ve sıra aralığının tane verimine etkisi ile bu çeşitlerin bazı fenolojik, morfolojik ve teknolojik karakterleri üzerine etkileri üzerinde bir araştırma,. Erzurum, $134 \mathrm{~s}$.

Anlarsal AE, Yücel C, Özveren D (2000). Çukurova koşullarında bazı fasulye (Phaseolus vulgaris L.) çeşitlerinde tane verimi ve verimle ilgili özellikler ile bu özellikler arası ilişkilerin saptanması. Turk $\mathbf{J}$ Agric For 24: 19-29.

Anonymous (2012). www.fao.org

Anonymous (2016). www.tuik.gov.tr

Anonymous (2017). www.tuik.gov.tr

Başçiftçi ZB (2012). Şeker mısır ve bodur fasulyenin karışık ekiminde ekim düzenlemeleri ve bazı agronomik özelliklerin belirlenmesi. Eskişehir Osmangazi Üniversitesi, Fen Bilimleri Enstitüsü, Tarla Bitkileri Anabilim Dalı, Doktora Tezi, Eskişehir.

Bozoğlu H, Sözen H (2007). Some agronomic properties of the local population of common bean (Phaseolus vulgaris L.) of Artvin province. Turk J. Agric For 31 327-334.

Bozoğlu H, Gülümser A (2000). Kuru fasulyede (Phaseolus vulgaris $L$.) bazı tarımsal özelliklerin genotip çevre interaksiyonları ve stabilitelerinin belirlenmesi üzerine bir araştırma. Turk J Agric For 24: 211-220.

Broughton WJ, Hernández G, Blair M, Beebe S, Gepts P, Vanderleyden J (2003). Beans (Phaseolus spp.)-model food legumes. Plant Soil 252: 55-128.

Ceyhan E, Kahraman A (2013). Genetic Analysis of Yield and Some Characters in Peas. Legume Research, 36 (4): 273-279.

Ceyhan E, Harmankaya M, Kahraman A (2014). Combining ability and heterosis for concentration of mineral elements and protein in common bean (Phaseolus vulgaris L.). Turkish Journal of Agriculture and Forestry, 38: 581-590.
Ceyhan E, Kahraman A, Ateş MK, Karadaş S (2012). Stability Analysis on Seed Yield and its Components in Pea. Bulg. J. Agric. Scie., 18 (6): 887-893.

Çiftçi CY, Şehirali S (1984). Fasulye (Phaseolus vulgaris L.) çeşitlerinde değişik özelliklerin fenotipik ve genotipik farklılıkların saptanması, Ankara Üniversitesi Fen Bilimleri Yayın No: TB.4.

Düzdemir O (1998). Kuru fasulye (Phaseolus vulgaris L.) genotiplerinde verim ve diğer bazı özellikler üzerine bir araştırma. Gazi Osman Paşa Üniversitesi, FBE Yüksek Lisans Tezi, Tokat.

Gillard CL, Ranatunga NK, Conner RL (2012). The control of dry bean anthracnose through seed treatment and the correct application timing of foliar fungicides. Crop Protection 37: 81-90.

Güneş Z (2011). Van-Gevaş' Da Ümitvar Bulunan Fasulye (Phaseolus vulgaris L.) Hatlarında Verim Ve Bazı Verim Ögelerinin Belirlenmesi. Yüzüncü Y1l Üniversitesi Fen Bilimleri Enstitüsü Tarla Bitkileri Ana Bilim Dalı. Yüksek Lisans Tezi.

Harmankaya M, Ceyhan E, Çelik AS, Sert H, Kahraman A, Ozcan MM (2016). Some Chemical Properties, Mineral Content and AminoAcid Composition of Cowpeas [Vigna sinensis (L.) Savi]. Quality Assurance and Safety of Crops \& Foods, 8 (1): 111116. DOI: 10.3920/QAS2014.0487. ISSN: 17578361.

Işık S (2012). Van ekolojik koşullarında kışlık arpa ve kışlık mercimek ekim alanlarında ikinci ürün olarak fasulye (Phaseolus vulgaris L.) yetiştirme olanaklarının araştırılması. Yüzüncü Yıl Üniversitesi Fen Bilimleri Enstitüsü Tarla Bitkileri Anabilim Dalı, Yüksek Lisans Tezi, Van.

Joshi DJ, Ravindrababu Y, Patel AM, Chauhan SS (2015). Heterosis studies for grain yield and it's contributing traits in field pea (Pisum sativum L. var. arvense). Asian Journal of Biological Sciences 10 (2): 158-161.

Kaçar O, Çakmak F, Çöplü N, Azkan N (2004). Bursa koşullarında bazı kuru fasulye çeşitlerinde (Phaseolus vulgaris $L$.) bakteri aşılama ve değişik azot dozlarının verim ve verim unsurları üzerine etkisinin belirlenmesi. U. Ün. Zir. Fak. Dergisi, 18(1): 207- 218.

Kahraman A, Önder M (2018). Accumulation of heavy metals in dry beans sown on different dates. $J$. Elem., $\quad 23(1)$ : $201-216 . \quad$ DOI: 10.5601/jelem.2017.22.2.1308.

Kahraman A, Önder M (2009). Konya bölgesinde yetiştirilen kuru fasulye (Phaseolus vulgaris L.) genotiplerinde verim ve bazı verim öğelerinin belirlenmesi. Türkiye VIII. Tarla Bitkileri Kongresi, Cilt 1, s. 309-313 (Sözlü Sunum). 19 22 Ekim, Hatay, 2009.

Kahraman A (2016). Nutritional components and amino acids in lentil varieties. Selcuk Journal of Agriculture and Food Sciences, 30 (1): 34-38. ISSN: 2458-8377. 
Kahraman A (2017). Nutritional value and foliar fertilization in soybean. Journal of Elementology, 22 (1): 55-66, DOI: 10.5601/jelem.2016.21.1.1106. WOS:000390783900005.

Kahraman A, Harmankaya M, Ceyhan E (2015). Nutritional Variation and Drought Tolerance in Chickpeas (Cicer arietinum L.). Journal of Elementology, 20 (2): 331-341, ISSN: 1644-2296, DOI: $10.5601 /$ jelem.2014.19.2.674.

Karadavut U, Özdemir S, Genç A (2005). Fasulye (Phaseolus vulgaris L.) bitkisinde regresyon denklemlerinin karşılaştırılması ve değişken azaltılması. Bitkisel Araştırma Dergisi (2005) 1: 11-16.

Kosev V, Naydenova Y (2015). Heritability of qualitative traits in forage pea (Pisum sativum L.). OnLine Journal of Biological Sciences 15 (4): 274.281.

Mendes MP, Botelho FBS, Ramalho MAP, Abreu AFB, Furtini IV (2008). Genetic control of the number of days to flowering in common bean. Crop Breeding and Applied Biotechnology 8: 279-282.

Önder M, Özkaynak İ (1994). Bakteri Aşılaması ve Azot Uygulamasının Bodur Kuru Fasulye Çesitlerinin Tane Verimi ve Bazı Özellikleri Üzerine 50 Etkileri. TÜBİTAK, Turkısh Journal of Agicultural and Forestry, $463-471$.

Önder M, Kahraman A (2008). Mercimek Çeşitlerinin Tanelerinde Bulunan Mineraller Arasındaki İlişkiler ve Kalite Üzerine Etkileri. Vol. 3, s. 102-109 (Poster Bildiri). Karadeniz Uluslararası Çevre Sempozyumu (BIES'08), 25 - 29 Ağustos 2008, Giresun Türkiye.

Önder M, Sade A (1996). Yunus 90 Bodur kuru fasulye çeşidinde farklı bitki sıklıklarının dane verimi ve verim unsurları üzerine etkileri. S.Ü. Zir. Fak. Dergisi, 9 (11): 71-82.

Önder M, Kahraman A, Ceyhan E (2013). Correlation and path analysis for yield and yield components in common bean genotypes (Phaseolus vulgaris L.). Ratar. Povrt., 50 (2): 14-19.

Pekşen E (2005). Samsun koşullarında bazı fasulye (Phaseolus vulgaris L.) genotiplerinin tane verimi ve verimle ilgili özellikler bakımından karşılaşt1rılması. OMÜ Z. F. Dergisi, 20 (3):88-95.

Singh KK, Malhotra RJ (1970). Interrelationshisps between yield and yield components in mungbean. Indian J. of Genetics and Plant Breeding, 30 (1): 244-250.

Singh KK, Hassan W, Singh SP, Prasad P (1976). Correlation and regression in gren gram (Phaseolus aureus Roxb.) Proc. Bihar Acad. Agric. Sci., 24 (1): 40-43.

Singh SP (1999). Integrated genetic improvement. In: Common bean improvement in the twentyfirst century. S. P. Singh (ed.). Kluwer Academic Publishers, Dordrecht, The Netherlands. pp. 133-165.

Şehirali S (1965). Türkiye'de yetiştirilen bodur fasulye çeşitlerinin tarla ziraati yönünden önemli başlica morfolojik ve biyolojik vasıfları üzerinde araştırmalar, Ankara Üniversitesi Ziraat Fakültesi Yayın No: 474, Bilimsel Araştırma ve İncelemeler: 275.

Şehirali S (1979). Yemeklik Tane Baklagiller T.C. Gıda-Tarım ve Hayvancılık Bakanlığı Ziraat İșleri Genel Müdürlüğü Yayınları. Ankara. S:8-65

Ülker M, Ceyhan E (2008). Orta Anadolu şartlarında yetiştirilen fasulye (Phaseolus vulgaris L.) genotiplerinin bazı tarımsal özelliklerinin belirlenmesi. S.Ü. Zir. Fak. Dergisi 22 (46): 83-96.

Yadav SK, Nanda HC, Nair SK, Gandley T, Sao M (2015). Heterosis studies for yield and quality attributes in field pea (Pisum sativum L.). Progressive Research - An International Journal 10 (Special VII): 3845-3848. 